Prepared in cooperation with the Tennessee Department of Environment and Conservation

\title{
Stage-Discharge Relations and Annual Nitrogen and Phosphorus Load Estimates for Stream Sites in the Elk River Basin, 2006-2008
}

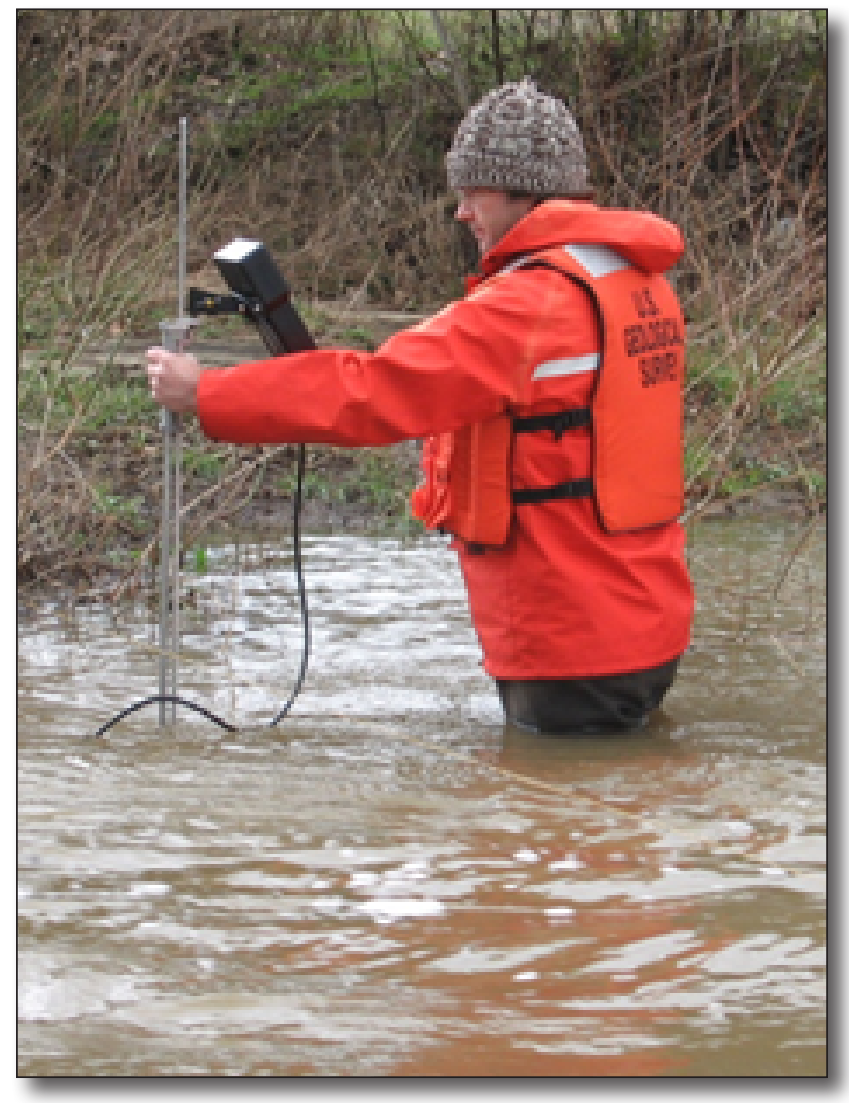

Data Series 1015 
Cover. USGS hydrologic technician David Boyd measuring stream discharge using a wading rod and current meter. (Photograph by Don League, U.S. Geological Survey.) 


\section{Stage-Discharge Relations and Annual Nitrogen and Phosphorus Load Estimates for Stream Sites in the Elk River Basin, 2006-2008}

By Anne B. Hoos, Shannon D. Williams, and William J. Wolfe

Prepared in cooperation with the Tennessee Department of Environment and Conservation

Data Series 1015 


\title{
U.S. Department of the Interior SALLY JEWELL, Secretary
}

\section{U.S. Geological Survey Suzette M. Kimball, Director}

\author{
U.S. Geological Survey, Reston, Virginia: 2016
}

For more information on the USGS - the Federal source for science about the Earth, its natural and living resources, natural hazards, and the environment—visit http://www.usgs.gov or call 1-888-ASK-USGS.

For an overview of USGS information products, including maps, imagery, and publications, visit http://store.usgs.gov.

Any use of trade, firm, or product names is for descriptive purposes only and does not imply endorsement by the U.S. Government.

Although this information product, for the most part, is in the public domain, it also may contain copyrighted materials as noted in the text. Permission to reproduce copyrighted items must be secured from the copyright owner.

Suggested citation:

Hoos, A.B., Williams, S.D., and Wolfe, W.J., 2016, Stage-discharge relations and annual nitrogen and phosphorus load estimates for stream sites in the Elk River Basin, 2006-2008: U.S. Geological Survey Data Series 1015, 9 p., http://dx.doi.org/10.3133/ds1015.

ISSN 2327-638X (online) 


\section{Acknowledgments}

This work was supported by the Tennessee Department of Environment and Conservation. The authors acknowledge the time and extra effort of individuals who provided water-quality monitoring data: Richard Cochran, David Duhl, and Regan McGahen, of the Tennessee Department of Environment and Conservation.

This work further benefitted from review comments and suggestions from Brandon Cobb, Jerry Garrett, and Rodney Knight, U.S. Geological Survey. The work of Paul David Boyd, a skilled and dedicated hydrologic technician who developed several of the discharge ratings for this report, is gratefully acknowledged. 


\section{Contents}

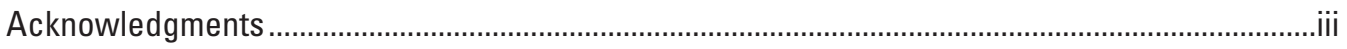

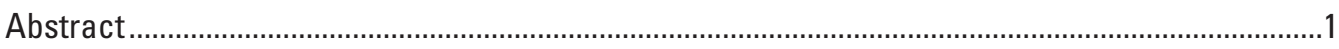

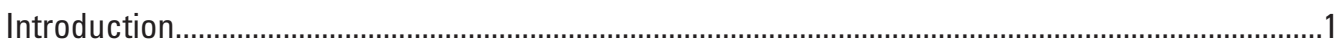

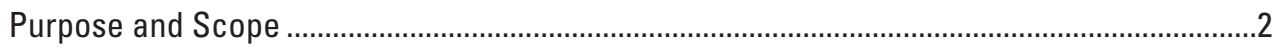

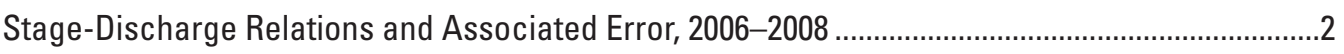

Annual Nitrogen and Phosphorus Load Estimates and Associated Error, 2006-2008......................2

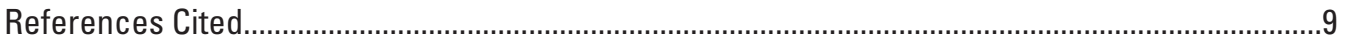

\section{Figure}

1. Location of nutrient water-quality monitoring sites in the Elk River Basin

in Tennessee, 2006-2008.

\section{Tables}

1. Nutrient water-quality monitoring sites in the Elk River Basin with associated continuous- or partial-record discharge sites, 2006-2008

2. Partial-record stage-discharge sites in the Elk River Basin, 2006-2008

3. Stage-discharge ratings for 10 partial-record stage-discharge sites in the Elk River Basin, available only online at http://dx.doi.org/10.3133/ds1015

4. Estimates of annual nitrogen and phosphorus load, yield, and concentration for four monitoring sites in the Elk River Basin, water years 2006-2008.

5. Estimates of annual nitrogen and phosphorus load and yield during 2002-2009 for two monitoring sites in the Elk River Basin, for comparison with conditions during 2006-2008. 


\section{Conversion Factors}

U.S. customary units to International System of Units

\begin{tabular}{|c|c|c|}
\hline Multiply & By & To obtain \\
\hline \multicolumn{3}{|c|}{ Length } \\
\hline foot $(\mathrm{ft})$ & 0.3048 & meter $(\mathrm{m})$ \\
\hline mile (mi) & 1.609 & kilometer $(\mathrm{km})$ \\
\hline \multicolumn{3}{|c|}{ Area } \\
\hline square mile $\left(\mathrm{mi}^{2}\right)$ & 259.0 & hectare (ha) \\
\hline square mile $\left(\mathrm{mi}^{2}\right)$ & 2.590 & square kilometer $\left(\mathrm{km}^{2}\right)$ \\
\hline \multicolumn{3}{|c|}{ Flow rate } \\
\hline cubic foot per second $\left(\mathrm{ft}^{3} / \mathrm{s}\right)$ & 0.02832 & cubic meter per second $\left(\mathrm{m}^{3} / \mathrm{s}\right)$ \\
\hline \multicolumn{3}{|c|}{ Mass } \\
\hline ton, short $(2,000 \mathrm{lb})$ & 0.9072 & megagram (Mg) \\
\hline ton per year (ton/yr) & 0.9072 & megagram per year (Mg/yr) \\
\hline ton per year (ton/yr) & 907.2 & kilogram per year (kg/yr) \\
\hline $\begin{array}{l}\text { ton per year per square mile } \\
{\left[(\operatorname{ton} / \mathrm{yr}) / \mathrm{mi}^{2}\right]}\end{array}$ & 0.3503 & $\begin{array}{l}\text { megagram per year per square kilometer } \\
\qquad\left[(\mathrm{Mg} / \mathrm{yr}) / \mathrm{km}^{2}\right]\end{array}$ \\
\hline $\begin{array}{l}\text { ton per year per square mile } \\
{\left[(\text { ton } / \mathrm{yr}) / \mathrm{mi}^{2}\right]}\end{array}$ & 350.3 & $\begin{array}{l}\text { kilogram per year per square kilometer } \\
{\left[(\mathrm{kg} / \mathrm{yr}) / \mathrm{km}^{2}\right]}\end{array}$ \\
\hline
\end{tabular}

Horizontal coordinate information is referenced to the North American Datum of 1983 (NAD 83). Concentrations of chemical constituents in water are given in milligrams per liter (mg/L).

A water year is the period from 0 ctober 1 to September 30 . It is designated by the calendar year in which it ends. 



\title{
Stage-Discharge Relations and Annual Nitrogen and Phosphorus Load Estimates for Stream Sites in the Elk River Basin, 2006-2008
}

\author{
By Anne B. Hoos, Shannon D. Williams, and William J. Wolfe
}

\section{Abstract}

The U.S. Geological Survey, in cooperation with the Tennessee Department of Environment and Conservation (TDEC), measured continuous discharge at 4 water-quality monitoring sites and developed stage-discharge ratings for 10 additional water-quality monitoring sites in the Elk River Basin during 2006 through 2008. The discharge data were collected to support stream load assessments by TDEC. Annual nitrogen and phosphorus loads were estimated for the four sites where continuous daily discharge records were collected. Reported loads for the period 2006 through 2008 are not representative of long-term mean annual conditions at the sites in this study, however, because of severe drought conditions in the Elk

River Basin during this period.

\section{Introduction}

Because nitrogen and phosphorus loads in the Elk River Basin (fig. 1) are among the highest in the Tennessee River Basin (Hoos and others, 2000), TDEC water-quality managers

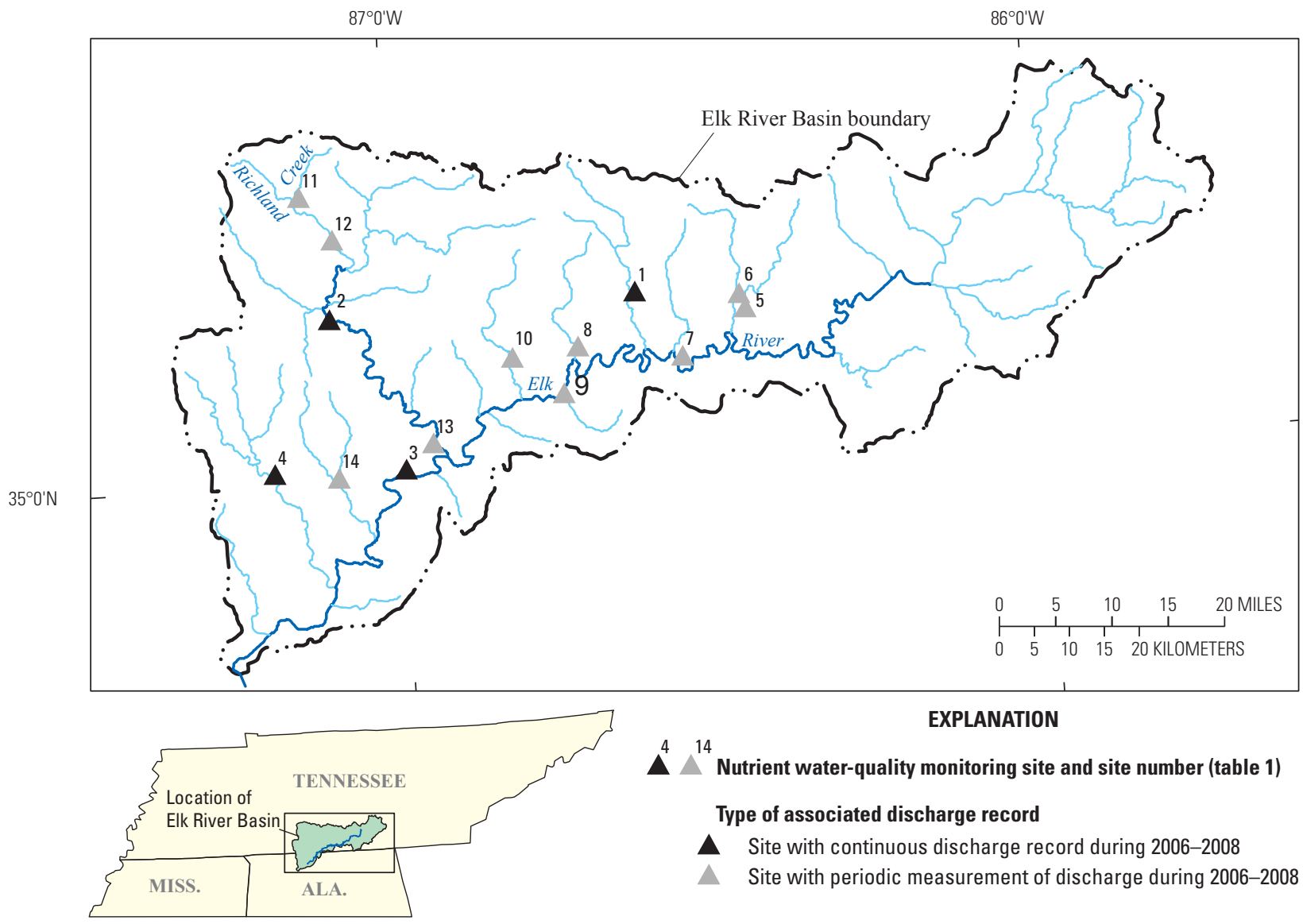

Figure 1. Location of nutrient water-quality monitoring sites in the Elk River Basin in Tennessee, 2006-2008 
need to account for natural and human-related variability of nutrient sources and transport throughout the basin. During 2006 through 2008, TDEC collected water samples at stream sites (fig. 1 and table 1) in the Elk River Basin and analyzed the samples for nitrogen and phosphorus concentration. The U.S. Geological Survey (USGS), in cooperation with TDEC, measured continuous discharge at 4 of the TDEC sampling sites and developed stage-discharge ratings for 10 additional sites (fig. 1 and table 2). Sites were selected to support efforts by the TDEC to assess and manage nutrient loadings to Tennessee streams. The continuous discharge records, combined with periodic measurements of nutrient concentration, enable estimation of annual nutrient loads. The stage-discharge ratings, combined with periodic measurements of nutrient concentration, enable estimation of instantaneous loads at the times of sample collection.

\section{Purpose and Scope}

The purpose of this report is to provide the stagedischarge ratings at 10 sites in the Elk River Basin and to report annual nitrogen and phosphorus load estimates for 4 sites where continuous daily discharge records were collected. The report includes notes on the methods used to characterize stage-discharge relations and estimates of annual loads and discussions of associated errors.

The current study addresses one of the six USGS science strategy goals, "Understanding Ecosystems and Predicting Ecosystem Change" (U.S. Geological Survey, 2007). The study also meets the science plan and goal of the USGS Lower Mississippi-Gulf Water Science Center to support Federal and State water-resources programs by collecting, interpreting, and disseminating quality-assured hydrologic data.

\section{Stage-Discharge Relations and Associated Error, 2006-2008}

Stage-discharge relations (ratings) were developed for 10 sites in the Elk River Basin (table 3, available at http:// dx.doi.org/10.3133/ds1015) from a graphical analysis of numerous discharge and stage measurements at each site. The methods used to develop the stage-discharge ratings are described by Kennedy (1984). All discharge measurements were made following standard procedures of measurement and quality control (Turnipseed and Sauer, 2010) and are permanently stored in the USGS National Water Information System (NWIS) database; the discharge measurement descriptions for the sites are available by accessing the hyperlinks in table 3. Some discharge measurements indicate a temporary change in the rating, typically because of a change in the streambed geometry (for example, erosion or deposition) or growth of riparian vegetation. Such changes are called shifts; they may indicate a short- or long-term change in the rating for the gage. Additional information on development and shifting of stage-discharge ratings is given by Kennedy (1984).

As a result of the limited amount of measurements (between 4 and 8) made at each of the 10 sites between summer 2006 and spring 2008, little is known about the extent and timing of shifts at these sites. The stage-discharge ratings should be considered provisional, and users are cautioned to carefully consider the applicability of these ratings.

Another reason for caution in the use of the stagedischarge ratings is that they do not cover the entire range of stages and discharges that occur at these sites. Discharge and stage were measured during a drought period in Tennessee, and opportunities to collect discharge measurements at higher stages were infrequent. The USGS only extends rating curves to twice as high as the highest flow measured (Rantz and others, 1982); therefore, these rating curves do not cover the entire range of stages and discharges that occur during wetter or possibly even normal hydrologic years.

\section{Annual Nitrogen and Phosphorus Load Estimates and Associated Error, 2006-2008}

Nitrogen and phosphorus loads were estimated for four sites with continuous discharge records (table 4) using daily discharge data and concentrations of unfiltered total nitrogen and total phosphorus. Daily discharge data collected by the USGS were retrieved from the USGS National Water Information System (NWIS; USGS, National Water Information System: Web Interface. http://waterdata.usgs.gov/nwis/sw, accessed October 26, 2012). Concentration data were collected by TDEC, stored in the U.S. Environmental Protection Agency's (USEPAs) Storage and Retrieval (STORET) database, and retrieved for this analysis from the Water Quality Portal (http://waterqualitydata.us/portal/, accessed October 27, 2012). Total nitrogen concentration (as N) was summed from the retrieved characteristics "Kjeldahl nitrogen" (sample fraction = Total) and "Inorganic nitrogen (nitrate and nitrite) as N" (sample fraction = Total). Total phosphorus concentration (as P) was taken from the retrieved characteristic "Phosphorus" $($ SampleFraction $=$ Total).

Loads were computed from the discharge and concentration data using bias-corrected, log-linear regression models within the program Fluxmaster (Schwarz and others, 2006) and based on methods described by Cohn and others (1989, 1992) and Gilroy and others (1990). Daily mean concentration was modeled by regressing the available instantaneous measurements of nutrient concentration against the variables discharge, season, and time: 
$\ln [C]=\beta 0+\beta 1(\ln [Q])+\beta 2(\ln [T])+$

$\beta 3(\operatorname{sine}[2 \pi T])+\beta 4(\operatorname{cosine}[2 \pi T])+\mathrm{e}$

where

$$
\begin{aligned}
\ln [] & \text { is natural logarithm function; } \\
C & \text { is instantaneous daily concentration, in } \\
& \text { milligrams per liter; } \\
Q & \text { is daily discharge, in cubic feet per second; } \\
T & \text { is time, in decimal years; } \\
\pi & \text { is 3.14169; } \\
\beta 0-\beta 4 & \begin{array}{l}
\text { are coefficients to be estimated in the } \\
\text { regression analysis; and }
\end{array} \\
\text { e } & \text { is model error. }
\end{aligned}
$$

The sine and cosine terms describe the pattern of seasonal variation. All of the available concentration and discharge record during water years 2002-2011 were used to develop the regression model of concentration and discharge for each site.

Daily mean load was then estimated as the product of estimated daily mean concentration and gaged daily discharge. The estimated daily values of mean load were then summed to produce a series of annual estimates of mean load; the annual estimates for water years 2006-2008 are reported in table 4 . Values of annual yield were computed as the ratio of load to drainage area (tons per year per square mile); values of annual flow-weighted mean concentration were computed as the ratio of load to discharge (milligrams per liter).

The standard error of the annual nitrogen load estimates, expressed as a percentage of the estimated value, ranged from 18 to 65 percent (table 4). The standard error of the annual phosphorus load estimates ranged from 10 to 94 percent, although for all estimates except for the site at Sugar Creek, the standard error was less than 30 percent. Larger values of percent standard error overall at one site compared to another site reflect greater uncertainty in the calibration of the daily concentration model (root mean square error, table 4) which in turn reflect poor fit of the regression model for concentration (equation 1); larger values of percent standard error for 1 year at a site compared to other years at that site reflect larger variance in flow for that year (Schwarz and others, 2006, p. 27). These error estimates do not account for the additional source of error introduced by estimating discharge from stagedischarge ratings. This additional error was not quantified but may be substantial, particularly for the Cane Creek and Sugar Creek sites for which the stage-discharge ratings were not well defined for higher flows and were extended above the highest discharge measurements of 4,280 cubic feet per second $\left(\mathrm{ft}^{3} / \mathrm{s}\right)$ for Cane Creek and 2,220 ft $\mathrm{ft}^{3} / \mathrm{s}$ for Sugar Creek.

Discharge data collection (but not water-quality data collection) occurred before and after the 2006-2008 period at two sites $(03584020$ and 03584600 , map identification numbers 2 and 3, respectively, fig. 1). For these sites, load can be estimated for the additional years (table 5) by extrapolating the concentration model beyond the period of water-quality data collection. The time series of annual mean discharge and load estimates at these two sites during 2002-2009 (table 5) delineate a sharp decline in discharge and load beginning in 2006 and emphasize the severity of the drought during the study period, particularly for 2007. The annual loads reported for the drought period 2006-2008 are much lower than loads for the other years and are not representative of long-term mean annual conditions at the sites in this study. 
Table 1. Nutrient water-quality monitoring sites in the Elk River Basin with associated continuous- or partial-record discharge sites, $2006-2008$.

[Water-quality monitoring sites operated by the Tennessee Department of Environment and Conservation; USGS, U.S. Geological Survey, mi² ${ }^{2}$ square miles]

\begin{tabular}{|c|c|c|c|c|c|c|c|c|}
\hline $\begin{array}{l}\text { Site number } \\
\text { (figure 1) }\end{array}$ & $\begin{array}{l}\text { Water-quality } \\
\text { monitoring site } \\
\text { identifier }\end{array}$ & $\begin{array}{c}\text { Associated } \\
\text { USGS discharge } \\
\text { gaging station } \\
\text { number }\end{array}$ & USGS station name & $\begin{array}{c}\text { Drainage } \\
\text { area, } \\
\text { in } \mathrm{mi}^{2}\end{array}$ & $\begin{array}{l}\text { Latitude, } \\
\text { decimal } \\
\text { degrees }\end{array}$ & $\begin{array}{l}\text { Longi- } \\
\text { tude, } \\
\text { decimal } \\
\text { degrees }\end{array}$ & $\begin{array}{l}\text { Number of } \\
\text { water- } \\
\text { quality } \\
\text { samples }\end{array}$ & $\begin{array}{c}\text { Daily discharge } \\
\text { record available } \\
\text { during } \\
2006-2008 ?\end{array}$ \\
\hline 1 & CANE008.1LI & 035825882 & CANE CREEK NEAR HOWELL, TN & 106 & 35.223 & -86.623 & 41 & Yes \\
\hline 2 & RICHL002.0GS & 03584020 & $\begin{array}{l}\text { RICHLAND CREEK AT HIGHWAY } 64 \text { NEAR PULASKI, } \\
\text { TN }\end{array}$ & 366 & 35.211 & -87.100 & 38 & Yes \\
\hline 3 & ELK036.5GS & 03584600 & ELK RIVER AT PROSPECT, TN & 1,805 & 35.014 & -86.995 & 41 & Yes \\
\hline 4 & SUGAR015.2GS & 03585269 & $\begin{array}{l}\text { SUGAR CREEK AT HIGHWAY } 11 \text { NEAR MINOR HILL, } \\
\text { TN }\end{array}$ & 125 & 35.017 & -87.198 & 31 & Yes \\
\hline 5 & EFMUL010.2MR & 03581250 & $\begin{array}{l}\text { EAST FORK MULBERRY CREEK AT MULBERRY- } \\
\text { KELSO ROAD NEAR MULBERRY, TN }\end{array}$ & 52.8 & 35.194 & -86.453 & 24 & No \\
\hline 6 & WFMUL001.4LI & 03581499 & $\begin{array}{l}\text { WEST FORK MULBERRY CREEK AT HIGHWAY } 50 \text { AT } \\
\text { MULBERRY, TN }\end{array}$ & 41 & 35.212 & -86.462 & 50 & No \\
\hline 7 & NORRI001.2LI & 03582315 & $\begin{array}{l}\text { NORRIS CREEK AT ADAMS STREET AT FAYETTE- } \\
\text { VILLE, TN }\end{array}$ & 45.5 & 35.137 & -86.555 & 44 & No \\
\hline 8 & SWAN000.8LI & 03582670 & SWAN CREEK AT EAST CYRUSTON, TN & 49 & 35.158 & -86.717 & 35 & No \\
\hline 9 & ELK064.0LI & 03582690 & ELK RIVER NEAR COLDWATER, TN & 1,105 & 35.099 & -86.743 & 54 & No \\
\hline 10 & BRADS001.3LI & 03583210 & BRADSHAW CREEK BELOW MCBURG, TN & 58 & 35.148 & -86.820 & 51 & No \\
\hline 11 & YOKLE000.1GS & 03583360 & YOKLEY CREEK NEAR CAMPBELLSVILLE, TN & 20.2 & 35.369 & -87.137 & 27 & No \\
\hline 12 & BIG004.9GS & 03583392 & $\begin{array}{l}\text { BIG CREEK AT KERR HILL ROAD NEAR CAMP- } \\
\text { BELLSVILLE, TN }\end{array}$ & 79.9 & 35.312 & -87.089 & 37 & No \\
\hline 13 & RICHL029.9GS & 03584400 & RICHLAND CREEK NEAR ELKTON, TN & 485 & 35.046 & -86.950 & 51 & No \\
\hline 14 & EFSHO000.2GS & 03585215 & EAST FORK SHOAL CREEK NEAR BETHEL, TN & 25.3 & 35.008 & -87.099 & 38 & No \\
\hline
\end{tabular}


Table 2. Partial-record stage-discharge sites in the Elk River Basin, 2006-2008.

[USGS, U.S. Geological Survey; $\mathrm{mi}^{2}$, square miles]

\begin{tabular}{|c|c|c|c|c|c|}
\hline $\begin{array}{l}\text { Site number } \\
\text { (figure 1) }\end{array}$ & $\begin{array}{l}\text { USGS discharge } \\
\text { gaging station } \\
\text { number }\end{array}$ & USGS station name & $\begin{array}{c}\text { Drainage } \\
\text { area, } \\
\text { in } \mathrm{mi}^{2}\end{array}$ & $\begin{array}{l}\text { Latitude, } \\
\text { decimal } \\
\text { degrees }\end{array}$ & $\begin{array}{r}\text { Longitude, } \\
\text { decimal } \\
\text { degrees }\end{array}$ \\
\hline 5 & 03581250 & $\begin{array}{l}\text { East Fork Mulberry Creek At Mulberry-Kelso Road Near } \\
\text { Mulberry, TN }\end{array}$ & 52.8 & 35.194 & -86.453 \\
\hline 6 & 03581499 & $\begin{array}{l}\text { West Fork Mulberry Creek At Highway } 50 \text { At } \\
\text { Mulberry, TN }\end{array}$ & 41 & 35.212 & -86.462 \\
\hline 7 & 03582315 & Norris Creek At Adams Street At Fayetteville, TN & 45.5 & 35.137 & -86.555 \\
\hline 8 & 03582670 & Swan Creek At East Cyruston, TN & 49 & 35.158 & -86.717 \\
\hline 9 & 03582690 & Elk River Near Coldwater, TN & 1,105 & 35.099 & -86.743 \\
\hline 10 & 03583210 & Bradshaw Creek Below Mcburg, TN & 58 & 35.148 & -86.820 \\
\hline 11 & 03583360 & Yokley Creek Near Campbellsville, TN & 20.2 & 35.369 & -87.137 \\
\hline 12 & 03583392 & Big Creek At Kerr Hill Road Near Campbellsville, TN & 79.9 & 35.312 & -87.089 \\
\hline 13 & 03584400 & Richland Creek Near Elkton, TN & 485 & 35.046 & -86.950 \\
\hline 14 & 03585215 & East Fork Shoal Creek Near Bethel, TN & 25.3 & 35.008 & -87.099 \\
\hline
\end{tabular}

Table 3. Stage-discharge ratings for 10 partial-record stage-discharge sites in the Elk River Basin. (Available online at http://dx.doi.org/10.3133/ds1015/) 
Table 4. Estimates of annual nitrogen and phosphorus load, yield, and concentration for four monitoring sites in the Elk River Basin, water years $2006-2008$.

[Annual estimates are reported for the period 2006-2008. Because flow and loading conditions vary widely from year to year, comparisons of yield among sites should be made for the common load estimation period, 2007-2008 (highlighted cells); USGS, U.S. Geological Survey; $\mathrm{ft}^{3} / \mathrm{s}$, cubic feet per second; ton/yr, tons per year; (ton/yr)/mi ${ }^{2}$, tons per year per square mile; $\mathrm{mg} / \mathrm{L}$, milligrams per liter; NE, not estimated]

\begin{tabular}{|c|c|c|c|c|c|c|c|c|}
\hline $\begin{array}{c}\text { Site } \\
\text { number } \\
\text { (figure 1) }\end{array}$ & $\begin{array}{l}\text { Water-quality } \\
\text { monitoring site } \\
\text { identifier }\end{array}$ & $\begin{array}{c}\text { USGS } \\
\text { discharge } \\
\text { gaging } \\
\text { station } \\
\text { number }\end{array}$ & USGS station name & $\begin{array}{c}\text { Water } \\
\text { year }\end{array}$ & $\begin{array}{c}\begin{array}{c}\text { Annual } \\
\text { mean }\end{array} \\
\text { discharge, } \\
\text { in } \mathrm{ft}^{3} / \mathrm{s}\end{array}$ & $\begin{array}{c}\text { Annual } \\
\text { nitrogen } \\
\text { load, in } \\
\text { ton/yr }\end{array}$ & $\begin{array}{c}\text { Annual } \\
\text { nitrogen } \\
\text { yield, in } \\
\text { (ton/yr)/ mi² }\end{array}$ & $\begin{array}{l}\text { Annual flow- } \\
\text { weighted } \\
\text { mean } \\
\text { nitrogen con- } \\
\text { centration, } \\
\text { in mg/L }\end{array}$ \\
\hline 1 & CANE008.1LI $^{1}$ & 035825882 & Cane Creek near Howell, TN & 2007 & 54 & 180 & 1.7 & 3.4 \\
\hline 1 & CANE008.1LI $^{1}$ & 035825882 & Cane Creek near Howell, TN & 2008 & 65 & 215 & 2.0 & 3.4 \\
\hline 2 & RICHL002.0GS & 03584020 & Richland Creek at Highway 64 near Pulaski, TN & 2006 & 463 & 1,031 & 2.8 & 2.3 \\
\hline 2 & RICHL002.0GS & 03584020 & Richland Creek at Highway 64 near Pulaski, TN & 2007 & 255 & 436 & 1.2 & 1.7 \\
\hline 2 & RICHL002.0GS & 03584020 & Richland Creek at Highway 64 near Pulaski, TN & 2008 & 379 & 729 & 2.0 & 2.0 \\
\hline 3 & ELK036.5GS & 03584600 & Elk River at Prospect, TN & 2006 & 2,067 & 1,461 & 0.8 & 0.7 \\
\hline 3 & ELK036.5GS & 03584600 & Elk River at Prospect, TN & 2007 & 1,228 & 1,010 & 0.6 & 0.8 \\
\hline 3 & ELK036.5GS & 03584600 & Elk River at Prospect, TN & 2008 & 1,329 & 1,432 & 0.8 & 1.1 \\
\hline 4 & SUGAR015.2GS ${ }^{1}$ & 03585269 & Sugar Creek at Highway 11 near Minor Hill, TN & 2007 & 85 & 62 & 0.5 & 0.7 \\
\hline 4 & SUGAR015.2GS ${ }^{1}$ & 03585269 & Sugar Creek at Highway 11 near Minor Hill, TN & 2008 & 132 & 97 & 0.8 & 0.8 \\
\hline
\end{tabular}


Table 4. Estimates of annual nitrogen and phosphorus load, yield, and concentration for four monitoring sites in the Elk River Basin, water years 2006-2008. - Continued

[Annual estimates are reported for the period 2006-2008. Because flow and loading conditions vary widely from year to year, comparisons of yield among sites should be made for the common load estimation period, 2007-2008 (highlighted cells); USGS, U.S. Geological Survey; $\mathrm{ft}^{3} / \mathrm{s}$, cubic feet per second; ton/yr, tons per year; (ton/yr)/mi ${ }^{2}$, tons per year per square mile; $\mathrm{mg} / \mathrm{L}$, milligrams per liter; NE, not estimated]

\begin{tabular}{|c|c|c|c|c|c|c|c|}
\hline $\begin{array}{c}\text { Site } \\
\text { number } \\
\text { (figure 1) }\end{array}$ & $\begin{array}{c}\text { Standard error } \\
\text { of annual nitrogen } \\
\text { load/yield } \\
\text { estimate, in percent }\end{array}$ & $\begin{array}{c}\text { Annual } \\
\text { phosphorus load, } \\
\text { in ton/yr }\end{array}$ & $\begin{array}{c}\text { Annual } \\
\text { phosphorus yield, } \\
\text { in }(\text { ton } / \mathrm{yr}) / \mathrm{mi}^{2}\end{array}$ & $\begin{array}{l}\text { Annual flow- } \\
\text { weighted mean } \\
\text { phosphorus } \\
\text { concentration, } \\
\text { in mg/L }\end{array}$ & $\begin{array}{c}\text { Standard } \\
\text { error of annual } \\
\text { phosphorus load/ } \\
\text { yield estimate, in } \\
\text { percent }\end{array}$ & $\begin{array}{l}\text { Root mean square } \\
\text { error for nitrogen } \\
\text { concentration model }\end{array}$ & $\begin{array}{l}\text { Root mean square } \\
\text { error for phosphorus } \\
\text { concentration model }\end{array}$ \\
\hline 1 & NE & 15 & 0.14 & 0.28 & 18 & $\mathrm{NE}$ & 0.37 \\
\hline 1 & NE & 16 & 0.15 & 0.25 & 15 & $\mathrm{NE}$ & 0.37 \\
\hline 2 & 42 & 65 & 0.18 & 0.26 & 10 & 0.57 & 0.22 \\
\hline 2 & 47 & 112 & 0.31 & 0.30 & 12 & 0.57 & 0.22 \\
\hline 3 & 31 & 542 & 0.30 & 0.27 & 26 & 0.41 & 0.44 \\
\hline 3 & 18 & 264 & 0.15 & 0.22 & 18 & 0.41 & 0.44 \\
\hline 3 & 18 & 358 & 0.20 & 0.27 & 19 & 0.41 & 0.44 \\
\hline 4 & NE & 5.4 & 0.04 & 0.07 & 74 & $\mathrm{NE}$ & 0.97 \\
\hline
\end{tabular}

${ }^{1}$ Annual nitrogen load estimates for Cane Creek near Howell, TN, and Sugar Creek at Hwy 11 near Minor Hill, TN, are expressed as an upper bound and displayed in italic font because a large proportion of concentration measurements were reported as below detection limit and therefore were not quantified; these load estimates do not have associated statistical measures of error (standard error of estimate, root mean square error) but are considered less accurate than the other estimates. 
Table 5. Estimates of annual nitrogen and phosphorus load and yield during 2002-2009 for two monitoring sites in the Elk River Basin, for comparison with conditions during 2006-2008.

[The period 2007-2008 (highlighted cells) is the common period for load estimation reported for the four continuous-record sites (table 4); USGS, U.S. Geological Survey; ft³/s, cubic feet per second; ton/yr, tons per year; (ton $/ \mathrm{yr}) / \mathrm{mi}^{2}$, tons per year per square mile]

\begin{tabular}{|c|c|c|c|c|c|c|c|c|c|c|c|}
\hline $\begin{array}{c}\text { Site } \\
\text { number } \\
\text { (figure 1) }\end{array}$ & $\begin{array}{l}\text { Water-quality } \\
\text { monitoring site } \\
\text { identifier }\end{array}$ & $\begin{array}{c}\text { USGS } \\
\text { discharge } \\
\text { gaging } \\
\text { station } \\
\text { number }\end{array}$ & USGS station name & $\begin{array}{l}\text { Water } \\
\text { year }\end{array}$ & $\begin{array}{c}\text { Annual } \\
\text { mean } \\
\text { discharge, } \\
\text { in } \mathrm{ft}^{3} / \mathrm{s}\end{array}$ & $\begin{array}{c}\text { Annual } \\
\text { nitrogen } \\
\text { load, in } \\
\text { ton/yr }\end{array}$ & $\begin{array}{c}\text { Annual } \\
\text { nitrogen } \\
\text { yield, in } \\
\text { (ton/yr)/ mi² }\end{array}$ & $\begin{array}{c}\text { Standard } \\
\text { error of an- } \\
\text { nual nitrogen } \\
\text { load/yield } \\
\text { estimate, in } \\
\text { percent }\end{array}$ & $\begin{array}{c}\text { Annual } \\
\text { phosphorus } \\
\text { load, } \\
\text { in ton/yr }\end{array}$ & $\begin{array}{c}\text { Annual } \\
\text { phosphorus } \\
\text { yield, } \\
\text { in (ton/yr)/mi² }\end{array}$ & $\begin{array}{c}\text { Standard } \\
\text { error of } \\
\text { annual } \\
\text { phosphorus } \\
\text { load/yield } \\
\text { estimate, } \\
\text { in percent }\end{array}$ \\
\hline 2 & RICHL002.0GS & 03584020 & $\begin{array}{l}\text { Richland Creek at Highway } 64 \\
\text { near Pulaski, TN }\end{array}$ & 2002 & 882 & 2,411 & 6.6 & 77 & 316 & 0.86 & 17 \\
\hline 2 & RICHL002.0GS & 03584020 & $\begin{array}{l}\text { Richland Creek at Highway } 64 \\
\text { near Pulaski, TN }\end{array}$ & 2003 & 1,074 & 2,893 & 7.9 & 76 & 429 & 1.2 & 18 \\
\hline 2 & RICHL002.0GS & 03584020 & $\begin{array}{l}\text { Richland Creek at Highway } 64 \\
\text { near Pulaski, TN }\end{array}$ & 2004 & 796 & 1,889 & 5.2 & 64 & 313 & 0.86 & 17 \\
\hline 2 & RICHL002.0GS & 03584020 & $\begin{array}{l}\text { Richland Creek at Highway } 64 \\
\text { near Pulaski, TN }\end{array}$ & 2005 & 876 & 2,170 & 5.9 & 65 & 327 & 0.89 & 17 \\
\hline 2 & RICHL002.0GS & 03584020 & $\begin{array}{l}\text { Richland Creek at Highway } 64 \\
\text { near Pulaski, TN }\end{array}$ & 2006 & 463 & 1,031 & 2.8 & 65 & 139 & 0.38 & 14 \\
\hline 2 & RICHL002.0GS & 03584020 & $\begin{array}{l}\text { Richland Creek at Highway } 64 \\
\text { near Pulaski, TN }\end{array}$ & 2007 & 255 & 436 & 1.2 & 42 & 65 & 0.18 & 10 \\
\hline 2 & RICHL002.0GS & 03584020 & $\begin{array}{l}\text { Richland Creek at Highway } 64 \\
\text { near Pulaski, TN }\end{array}$ & 2008 & 379 & 729 & 2.0 & 47 & 112 & 0.31 & 12 \\
\hline 2 & RICHL002.0GS & 03584020 & $\begin{array}{l}\text { Richland Creek at Highway } 64 \\
\text { near Pulaski, TN }\end{array}$ & 2009 & 574 & 1,256 & 3.4 & 54 & 204 & 0.56 & 15 \\
\hline 3 & ELK036.5GS & 03584600 & Elk River at Prospect, TN & 2004 & 3,458 & 1,511 & 0.84 & 62 & 1,145 & 0.63 & 47 \\
\hline 3 & ELK036.5GS & 03584600 & Elk River at Prospect, TN & 2005 & 3,707 & 2,236 & 1.2 & 51 & 1,163 & 0.64 & 39 \\
\hline 3 & ELK036.5GS & 03584600 & Elk River at Prospect, TN & 2006 & 2,067 & 1,461 & 0.81 & 31 & 542 & 0.30 & 26 \\
\hline 3 & ELK036.5GS & 03584600 & Elk River at Prospect, TN & 2007 & 1,228 & 1,010 & 0.56 & 18 & 264 & 0.15 & 18 \\
\hline 3 & ELK036.5GS & 03584600 & Elk River at Prospect, TN & 2008 & 1,329 & 1,432 & 0.79 & 18 & 358 & 0.20 & 19 \\
\hline 3 & ELK036.5GS & 03584600 & Elk River at Prospect, TN & 2009 & 2,845 & 4,592 & 2.5 & 21 & 1,004 & 0.56 & 21 \\
\hline 3 & ELK036.5GS & 03584600 & Elk River at Prospect, TN & 2010 & 3,107 & 6,506 & 3.6 & 24 & 1,031 & 0.57 & 20 \\
\hline
\end{tabular}




\section{References Cited}

Cohn, T.A., Delong, L.L., Gilroy, E.J., Hirsch, R.M., and Wells, D.K., 1989, Estimating constituent loads: Water Resources Research, v. 25, no. 5, p. 937-942.

Cohn, T.A., Gilroy, E.J., and Baier, W.G., 1992, Estimating fluvial transport of trace constituents using a regression model with data subject to censoring, in Proceedings of the Section on Statistics and the Environment, Boston, Mass., August 9-13, 1992: American Statistical Association, p. $142-151$.

Gilroy, E.J., Hirsch, R.M., and Cohn, T.A., 1990, Mean square error of regression-based constituent transport estimates: Water Resources Research, v. 26, no. 9, p. 2069-2077.

Hoos, A.B., Robinson, J.A., Aycock, R.A., Knight, R.R., and Woodside, M.D., 2000, Sources, instream transport, and trends of nitrogen, phosphorus, and sediment in the lower Tennessee River Basin, 1980-96: U.S. Geological Survey Water-Resources Investigations Report 99-4139, 96 p. [Also available at http://pubs.usgs.gov/wri/wri994139/.]
Kennedy, E.J., 1984, Discharge ratings at gaging stations: U.S. Geological Survey Techniques of Water-Resources Investigations, book 3, chap. A10, 59 p. [Also available at http:// pubs.usgs.gov/twri/twri3-a10/.]

Rantz, S.E., and others, 1982, Measurement and computation of streamflow-Volume 2. Computation of discharge: U.S. Geological Survey Water-Supply Paper 2175, p. 285-631. [Also available at http://pubs.usgs.gov/wsp/wsp2175/.]

Schwarz, G.E., Hoos, A.B., Alexander, R.B., and Smith, R.A., 2006, The SPARROW surface water-quality model-Theory, application and user documentation: U.S. Geological Survey Techniques and Methods, book 6, section B, chap. 3, accessed August 6, 2007, at http://pubs.usgs.gov/tm/2006/ tm6b3/.

Turnipseed, D.P., and Sauer, V.B., 2010, Discharge measurements at gaging stations: U.S. Geological Survey Techniques and Methods book 3, chap. A8, 87 p. [Also available at http:// pubs.usgs.gov/tm/tm3-a $8 /$.

U.S. Geological Survey, 2007, Facing tomorrow's challengesU.S. Geological Survey science in the decade 2007-2011: U.S. Geological Survey Circular 1309, 67 p.

Publishing support provided by:

Lafayette Publishing Service Center

For more information concerning this publication, contact:

Chief, USGS Lower Mississippi-Gulf Water Science

Center-Tennessee (LMGWSC)

640 Grassmere Park, Suite 100

Nashville, TN 37211

(615) $837-4700$

Or visit the LMGWSC Web site at:

http://tn.water.usgs.gov/ 


